\author{
Marzena Makowska-Iskierka \\ University of Łódź \\ Institute of Urban Geography and Tourism Studies \\ marzena.makowska@geo.uni.lodz.pl
}

\title{
THE ROLE OF THE INHABITANTS OF ŁÓDŹ IN THE URBANISATION OF ITS SURROUNDING AREA
}

\begin{abstract}
This article describes the urbanisation process within the recreational region surrounding Łódź. After an introduction to theoretical issues, the topic will be the ongoing changes, their stages, and effects on various planes of this urbanisation. The emphasis is put on showing the characteristics and scale of the process, its causes and social features. The paper concludes by demonstrating the dominating influence of the inhabitants of Łódź on urbanisation processes caused by their tourism and recreational activity in this area.
\end{abstract}

Keywords: urbanisation, tourism urbanisation, space of tourism urbanisation, city surrounding area, suburbanisation.

\section{INTRODUCTION}

Wealthy inhabitants of large cities who dream about having their own cottage with a garden to enjoy nature every day and to rest from the city's noise after work, are becoming more inclined to move to the area surrounding the city. Tourism locations, like those near Łódź, are well connected with the city and have a good infrastructure, while providing peace, quiet and closeness to nature. The owners of such recreational homes often refurbish them with the idea of moving in permanently, or they build new ones. This phenomenon is called tourism urbanization, it is propelled by city dwellers and it has many-sided and long-lasting consequences on many planes: demographic, economic, spatial-physiognomic and cultural. Those who move from a large city, used to a high standard of living, contribute to development which in turn, as J. DZIECIUCHOWICZ (1995) has noted, introduces variety to those areas' economic functions and increases tourism potential. Migrants change their urban way of life, but also bring patterns of previous behaviour with them.

The topic of this article is an attempt to determine and evaluate the influence of Łódź inhabitants on transformations resulting from their tourism activity in the area surrounding the city. These speculations are based on ongoing observation by the author as well as literature analysis, statistical data (Roczniki statystyczne województwa tódzkiego) and the results of her own research from 2003-6 in 24 tourism locations surrounding Łódź. The information presented here from the early 2000s was obtained thanks to an original research method consisting of unrepeatable (due to increasing difficulties in obtaining personal data) and very detailed field observation and recording. Information about the inhabitants and owners of plots, as well as the buildings, is complete and comes from gmina and district authority offices (residence cards, plot index extracts and tax registries among others). The information was supplied by interviews, and an inventory taken directly from the researched areas. The results generated have not been published before although some were included in the text of the author's doctoral thesis (MAKOWSKA-ISKIERKa 2009).

The area surrounding Łódź, including its recreational function, was defined and described by A. MATCZAK (1981). 24 tourism locations (Fig. 1) which had an advanced tourism function ${ }^{1}$ in 1980 were taken into detailed consideration, on the assumption that urbanisation is most intense in places with a developed tourism function and therefore will be more noticeable today.

The examined tourism-recreational locations from the area surrounding Łódź, are also placed in the Łódź Metropolitan Area. According to Conceptions of spatial development... (2011), urban functional areas include the city and urban areas functionally connected with it. 


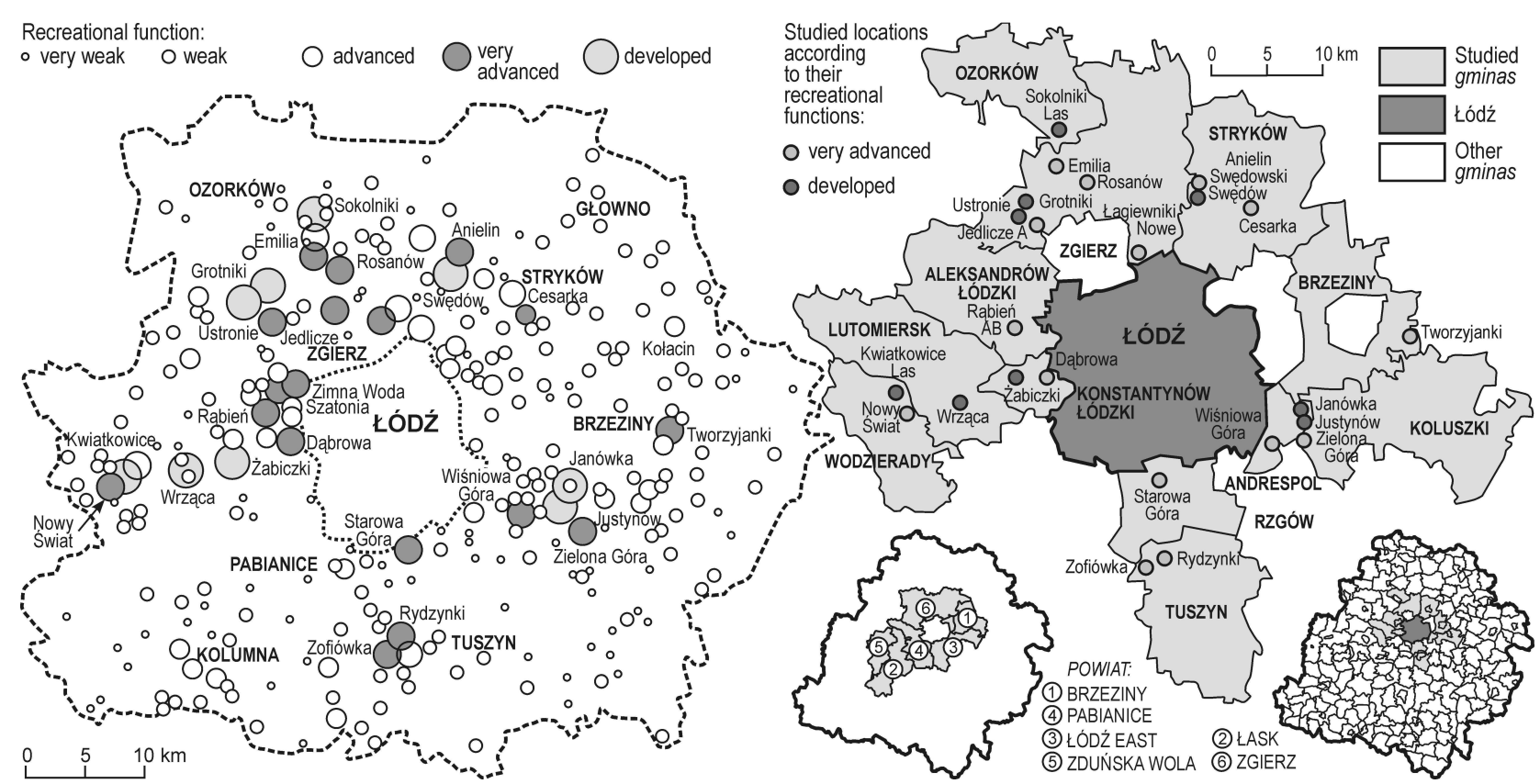

Fig. 1. Research area against the area surrounding Łódź, the Łódż Metropolitan Area and Łódzkie voivodeship Source: author based on A. MATCZAK (1981)

In the case of a metropolitan tourism-recreational region $^{2}$ its extent is often associated with the area surrounding the city (LISZEWSKI 2005, FARACIK 2011). In literature, the area surrounding the city is perceived as place of a mingling between urban and rural ways of life (KOTER 1985). These areas are connected to the city in a system of functional dependencies and undergo transformation under the city's influence. They are also a place of active urbanisation on functional, morphological, demographical and social planes.

\section{IDEAS, RESEARCH PHASES OF TOURISM URBANISATION}

Urbanisation is a complex, multi-faceted and usually long-term process of transformation and change, including processes connected with the spreading of a so-called urban lifestyle (e.g. ZIÓŁKOWSKI 1965). Tourism urbanisation is a part of the general urbanisation phenomenon. This term, used since the 1960s in European literature to describe changes happening due to tourism in rural areas was defined and verified in Poland by E. DZIEGIEĆ $(1987,1988,1995)$. It is a complex process, consisting of several phases and aiming at multi-faceted and permanent transformation of rural areas into urban. Functional transformation happens due to the development of tourism. These processes are caused in particular by city inhabitants who seasonally increase the population of attractive rural areas, often commuting to work in the city. Together with population, a transfer of capital and behavioural patterns is found (DZIEGIEĆ 1995) while the intensity of urbanisation depends on the time they fulfilled a recreational function (MAKOWSKA-ISKIERKA 2011). According to A. KOWALCZYK (1994), it is expressed through 'second homes' 3 , which over time are transformed into main residences. S. LISZEWSKI (2005) notes that apart from the functional plane described, changes in physiognomic and spatial planes, are connected to changes in architecture and spatial organization. According to S. LISZEWSKI (2005) tourism urbanisation is most visible in the areas around large cities that have been previously colonized touristically and later transformed into suburbs with permanent residents.

Tourism urbanisation leads to the development of a distinctive kind of tourism space ${ }^{4}$ termed recreational or tourism-recreational. This space, distinguished from the surroundings by its function and development, undergoes transformation by visiting and making use of it for tourism and recreation purposes. The changes are influenced by the activities of the inhabitants of large cities most of all choosing these locations as their recreational space. Their impact increases with the frequency and length of visits. Tourism urbanisation space is the highest organized type of tourism subspace (LISZEWSKI 1995, WŁODARCZYK 1999). In this most advanced phase of tourism space transformation the location no longer fulfils the 
initial recreational function, but develops a new housing function due to the permanent movement of city inhabitants to rural areas previously colonized touristically. Even though tourism development remains high, the intensity of tourism declines.

Rural area transformation due to the development of tourism is a research subject in many parts of the country (e.g. DĄBROWSKA 1996). Researchers are also interested in recreational locations in areas surrounding Polish cities, documented in literature overviews by R. FARACIK $(2006,2011)$. Tourism in Łódź and its surrounding area is one of the key issues for the lecturers of the Institute of Urban Geography and Tourism Studies (MATCZAK 1981, 1984, 1985, 1986, 1987, 1995, 1996, Tourisme... 1983, JAKÓBCZYK-GRYSZKIEWICZ 1995, Studium wiedzy... 1995, LISZEWSKI 1999; Ruch turystyczny... 2012, KRAKOWIAK et al. 2014). A. MATCZAK (1982) researched the recreational function of the area surrounding Łódź, E. DZIEGIEĆ \& S. LISZEWSKI (1984) researched its evolution and role in satisfying the needs of city dwellers, S. LISZEWSKI (1987) wrote about the genesis and development of its recreational settlement, B. WŁODARCZYK (1999) and R. SZKUP (2003) discussed the development of the suburban recreational space, and M. MAKOWSKA-ISKIERKA (2004) dealt with the subject of the transformation of the tourism-recreational function of locations near Łódź. J. JAKÓBCZYK-GRYSZKIEWICZ (1988, 1991, 1998) researched the subject of the urbanisation of rural areas, and M. MAKOWSKA-ISKIERKA (2005, 2006, 2010, $2011,2013)$ studied the consequences of those changes taking place in tourism-recreational locations on various levels: demographic-professional, economic, spatial-physiognomic and cultural.

Urbanisation takes place in various spheres but its main causative agent is human activity and decisions. The need for rest in a natural environment, so significant for inhabitants of large cities has caused the development of natural areas located nearby and well-connected to the city. At first, a summer cottage would be rented from its owners. Wealthy townspeople had built their own summer residences, usually in wooded areas as early as in the $19^{\text {th }} \mathrm{c}$. (STEJSKAE 1992). In the 1950s this became a mass trend which resulted in building summer houses on individual plots and mass recreation centres (LISZEWSKI 1987). In consequence, such areas had to be adjusted to their new functions with appropriate transformation. Tourism settlements were often built in previously uninhabited locations with designs inspired by Howard's garden cities - popular in Poland in the interwar period (MAKOWSKA-ISKIERKA \& WŁODARCZYK 2012). Since the beginning of the 1990s 'second homes' that could be used not only in the summer season appeared. Nowadays, it is becoming popular to adjust an existing house, or build a new one as a permanent place of residence contributing to the migration of people, mainly from cities. It is the next, more advanced stage of transforming tourism space into urbanized space ${ }^{5}$ The stages of transformation taking place in recreational areas, the urbanisation model and consequent conditions were described in detail by M. MAKOWSKA-ISKIERKA $(2008,2011)$.

\section{RESEARCH RESULTS}

The process of the 'deconcentrating' of urban populations witnessed in Poland is connected with the change of social-economic system and is called suburbanization. This process takes place in the Łódź Metropolitan Area, and has caused a decline in population in the core (mainly in Łódź) and negative

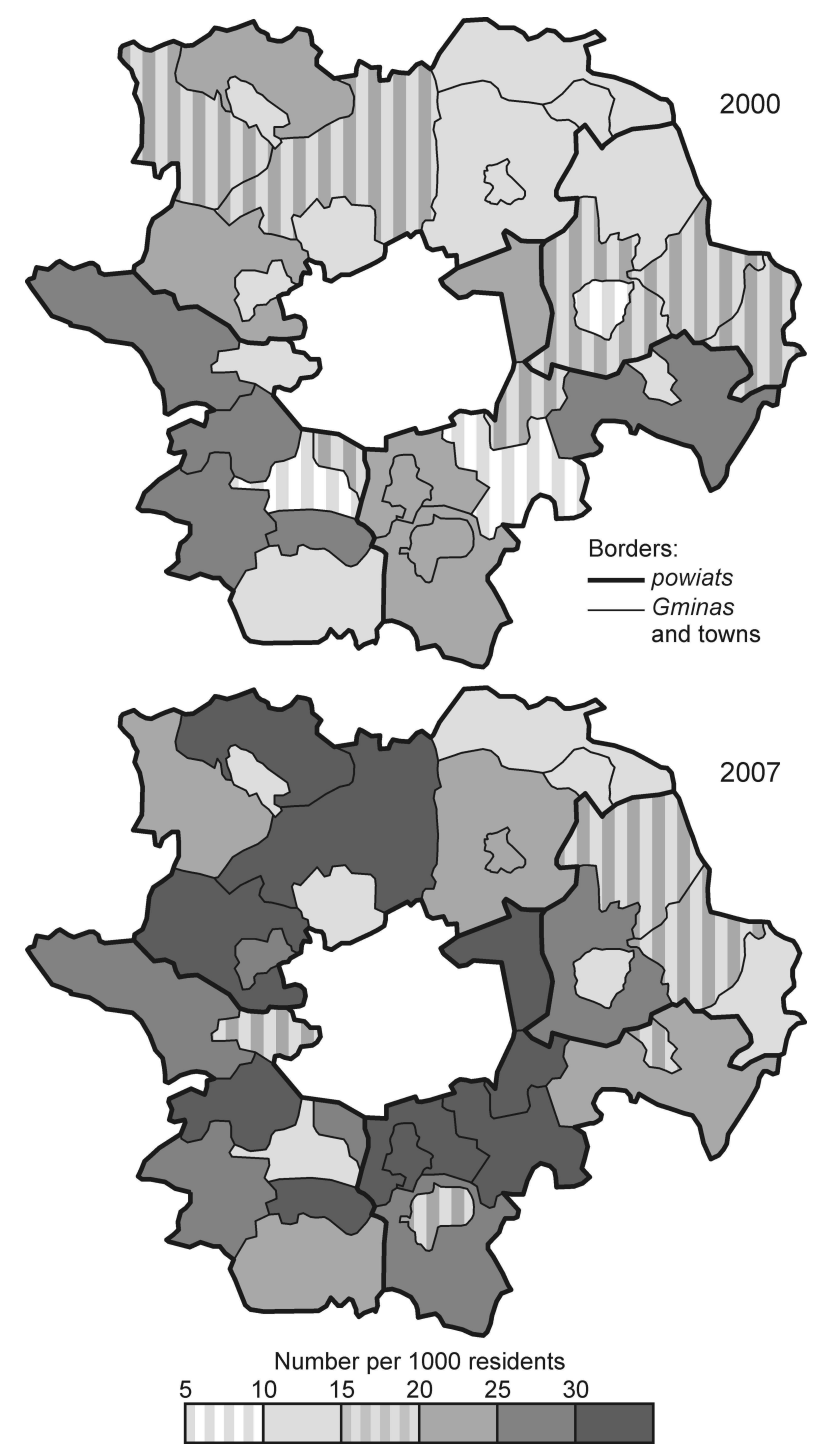

Fig. 2. Migration from Łódź to Łódź Municipal Area: 1997-2007 Source: J. JAKÓBCZYK-GRYSZKIEWICZ, S. MARCIŃCZAK \& SIEJKOWSKA (2010) 
population growth connected with an ageing society and migration to the countryside. J. JAKÓBCZYK-GRYSZKIEWICZ (2011) claims that the highest population growth was found within the outer limits of the core and the nearer part of the surrounding area, including recreational locations (Fig. 2). Migration from the city to Łódź Municipal Area is becoming increasingly popular, and is dominated by former Łódź inhabitants, who comprised nearly one third of the population in 1991-2000 and over $40 \%$ in 2007.

The recreational locations studied were in five different powiats of Łódzkie voivodeship, and researchers have noticed an increase in permanent migration. The largest number of registrations of residence was noted in Zgierz powiat (Table 1), where 11 out of 24 tourism gminas analysed were located. The migration of Łódż inhabitants to Zgierz in years 1989-2007 was over $40 \%$. Pabianice Powiat (later named Łódź East Powiat) had a significant share of over $30 \%$. Combined input into internal migration from Brzeziny, Łask, Łódź East, Pabianice and Zgierz Powiats in 2003 was $25.42 \%$. It is worth noting, that over half of migrants registered in the studied recreational locations were citizens of Łódź (Table 1), whereas in a quarter of powiats they were the only people who decided to register permanently, and in the other three they made up over $75 \%$.

The scale of migration in 2003 was largest in Łódź East and Zgierz Powiats. In the same year the combined number of registrations in those areas was respectively $60.66 \%$ and $34.45 \%$ of the total for each powiat. It did not exceed one third in other powiats.

Among 12 powiats, only one - Andrespol - had a half of new inhabitants who chose tourism locations, while Rzgów and Zgierz Powiats had a high share of $44 \%$ and Stryków Powiat had $24 \%$. Considering the fact that there were individual tourism locations within those powiats, the scale of migration, $9.74 \%$ on average, is significant. The largest number of registrations, both in absolute numbers (102) and in reference to the figure for the whole gmina $(44.74 \%)$ and powiat (6.88\%) was for Stalowa Góra located near the southern border of Łódź. Many people moved into Justynów and Wiśniowa Góra - in total $29.51 \%$ of all new inhabitants registered in 2003.

Over the last 15 years, the percentage who moved from the city to one of the 12 powiats analysed was on average $83.83 \%$, while their share in the sum of registration in Łódzkie voivodeship was 7-12\% and increasing annually (except 2005 and 2012). In turn, the share of those five powiats was between 23 and $28 \%$ in 2000-14 and also increasing. The situation from the beginning of the 2000s, similar to the current situation, follows the trend of internal migration found after 1989 and described in Próba delimitacji obszaru metropolitalnego Łodzi... (2008). The balance in Łódź has been negative in recent years due to the high rate of population outflow (6\% 1989-2007) but positive in the powiats surrounding Łódź. The main directions of outflow have been expanded, at first (1989-93) surrounding settlements were chosen such as Aleksandrów Łódzki, Pabianice and Zgierz, and also Konstantynów Łódzki and Andrespol Powiats, and in 2002-7, Andrespol along with Aleksandrów Łódzki and Zgierz Powiats, directly adjoining Łódź. A high level of relocation between Łódź and surrounding powiats (Zgierz, Pabianice and Łódź East) reaching over 50\% proves that those powiats are in the process of metropolitisation.

The number of new inhabitants registering residence in gminas surrounding Łódź exceeded the number cancelling their registration (even in the cities)

Table 1. Size of migration influx to selected administrative units in the area surrounding Łódź in 2003

\begin{tabular}{|c|c|c|c|c|c|}
\hline \multirow{3}{*}{ Municipality } & \multirow{3}{*}{ Municipality } & \multicolumn{4}{|c|}{ Migration influx (number of registrations) to } \\
\hline & & \multirow{2}{*}{ counties } & \multirow{2}{*}{ municipalities } & \multicolumn{2}{|c|}{ Studied locations } \\
\hline & & & & in general & including Łódź \\
\hline Brzeziński & Brzeziny & 339 & 111 & 1 & 0 \\
\hline Łaski & Wodzierady & 689 & 29 & 2 & 1 \\
\hline \multirow{4}{*}{$\begin{array}{l}\text { Łódzki } \\
\text { wschodni }\end{array}$} & Andrespol & \multirow{4}{*}{1,482} & 382 & 206 & 141 \\
\hline & Koluszki & & 220 & 12 & 10 \\
\hline & \begin{tabular}{|l|} 
Rzgów \\
\end{tabular} & & 228 & 102 & 25 \\
\hline & Tuszyn & & 69 & 8 & 8 \\
\hline \multirow[t]{2}{*}{ Pabianicki } & Konstantynów Łódzki & \multirow{2}{*}{1,542} & 245 & 32 & 15 \\
\hline & Lutomiersk & & 179 & 20 & 9 \\
\hline \multirow[t]{4}{*}{ Zgierski } & Aleksandrów Łódzki & \multirow{4}{*}{2,189} & 236 & 21 & 21 \\
\hline & Ozorków & & 87 & 8 & 8 \\
\hline & Stryków & & 175 & 42 & 8 \\
\hline & Zgierz & & 278 & 122 & 46 \\
\hline \multicolumn{2}{|l|}{ Sum } & 6,241 & 2,239 & 576 & 292 \\
\hline
\end{tabular}

Source: author based on GUS data (Łódzkie voivodeship statistical yearbook) and residence cards. 
which is an unusual situation for a rural area. This confirms the phenomenon of migration from cities. Those who decide to move, choose tourism locations with natural attractions.

Tourists, as broadly defined, are the medium of tourism urbanisation, but in the suburban areas, the key role is taken by the owners and users of plots, especially those who decided to settle in recreational areas. Detailed research by the author on 24 tourism locations surrounding Łódź shows that in 2004, Łódź inhabitants were the largest group among the 24936 plot owners and 11,573 permanent residents, 59.6 and $28.7 \%^{6}$ of the whole respectively. The share of the remaining inhabitants of Łódzkie voivodeship was 19.02 and $22.83 \%$ respectively, but they originated mostly from small towns and villages neighbouring the tourism areas. Interestingly, former inhabitants of Łódź exceeded the number who had lived in such places since birth $(26.85 \%)$. Another significant group were registered plot owners $(18.04 \%)$, and three quarters had previously lived in Łódź. The vast majority $(76.58 \%)$ originated from cities and $77.84 \%$ were from Łódź.

In conclusion, it is the inhabitants of Łódź who influence the speed and direction of the transformations taking place in the tourism-recreational locations in its surrounding areas.
The highest number of Łódź inhabitants deciding to move after 1989 (81.77\% registered between 1991 and 2004) and especially in the early 2000s (previous inhabitants of Łódź comprised over half of all those registering their residence Fig. 3). This was confirmed by a high level of interdependence (Pearson correlation coefficient calculated for the percentage of former Łódź inhabitants and year of registration, was $r=0.8$ ).

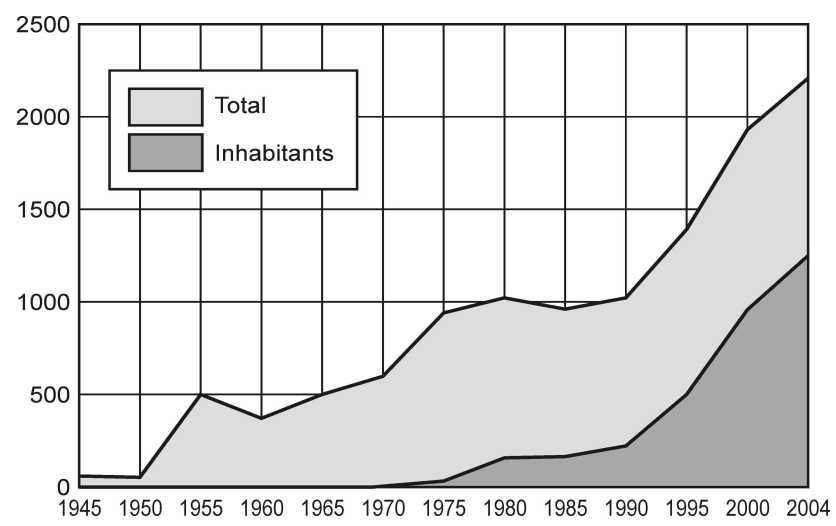

Fig. 3. The number of permanently registered inhabitants of tourism-recreational areas surrounding Łódź, including those from Łódź (as in 2004)

Source: author based on information from residence cards

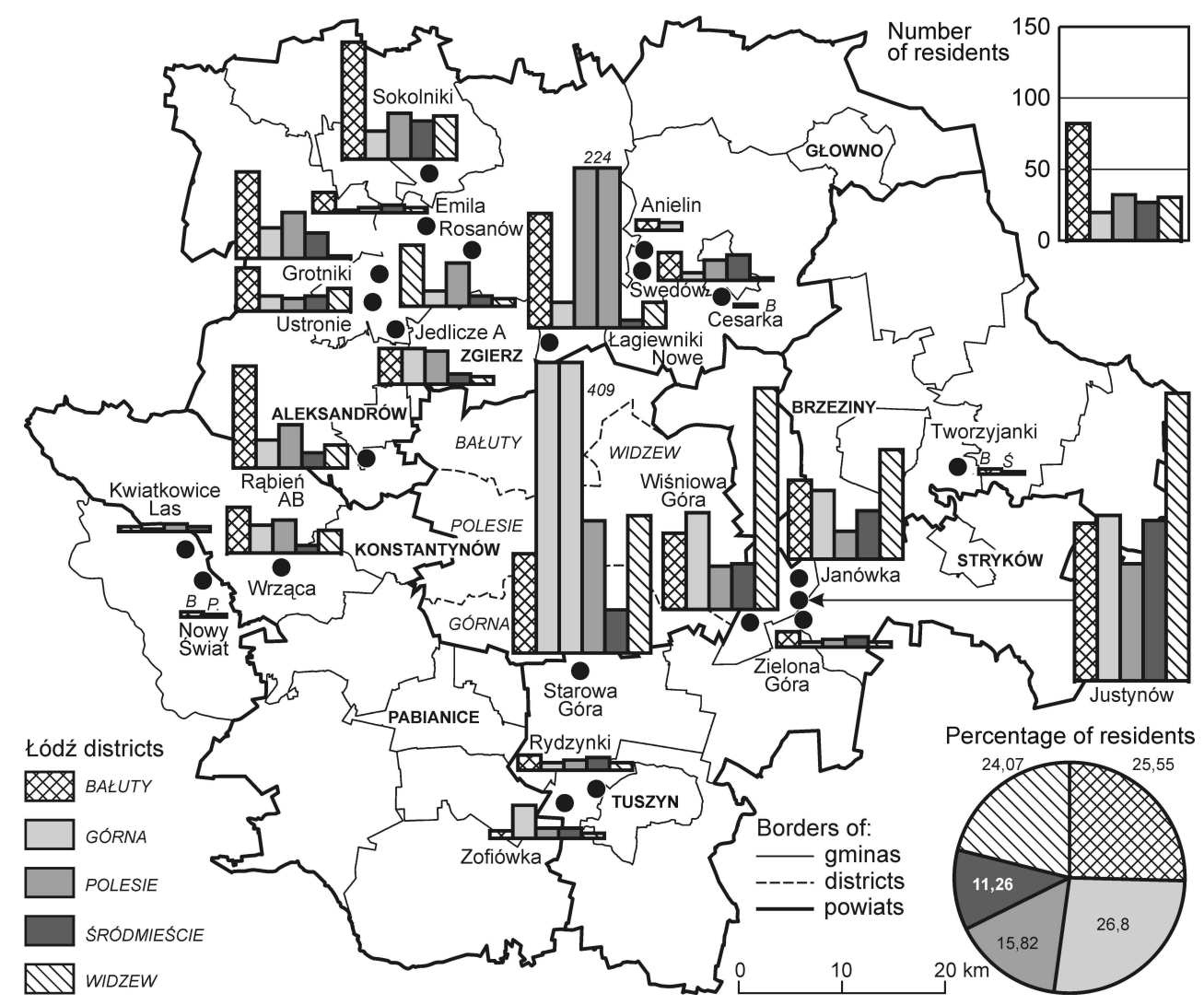

Fig. 4. District of origin of the inhabitants of recreational areas from Łódź in 2004 (without data on Żabiczki and Dąbrowa) Source: author based on residence cards 
Those who moved from Łódź to one of its neighbouring towns $(3,320$ in 2004) previously lived in the districts of Bałuty and Górna (over one quarter) and Widzew (around one fifth). Only one in ten originated from Śródmieście, and 15\% from Polesie, which means less than from the first two districts. Analysing the locations they moved to, it can be seen that they usually chose neighbouring areas, for example, the inhabitants of Widzew moved east to the gminas of Andrespol; and the inhabitants of Gorna moved south to Rzgów and Tuszyn Powiats; those from Bałuty moved north, mostly to gminas in Zgierz Powiat (Zgierz, Ozorków and Aleksandrów Łódzki); and the inhabitants of Polesie west, mostly to Łask Powiat (Fig. 4).

Taking Łódź districts into consideration, the distribution of plot owner residences proves a significant polarisation of tendencies. The dominating group were the inhabitants of districts located closest to the reception places which indicates the importance of distance. Previous inhabitants of Łódź who moved to areas surrounding the city usually chose close locations with good connections.

The age structure of inhabitants is favourable compared to that of traditional villages. The increase in permanent residency of people at working age $(74.78 \%)$ prevents depopulation of the powiat. Inhabitants of Łódź were on average aged 33 when registering residence. The largest group was between 21 and 55 , and was $60.74 \%$ of the whole (Fig. 5). Usually, whole families migrated, as seen in the high percentage of children (20.84\% below 18$)$. Interestingly, a relatively small number of children were born after moving, just $1.43 \%$. The situation is different from the trend observed in western European countries, where migration out of the city is usually by elderly, retired people. The main reason here might be the fact that pensioners in Poland usually lack sufficient funds to afford to move.

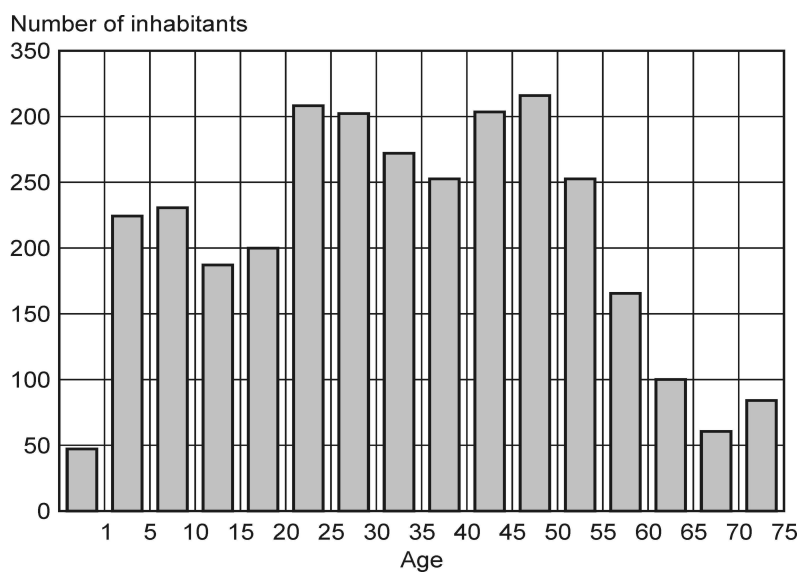

Fig. 5. Age of Łódź inhabitants when obtaining permanent registration in recreational locations in the area surrounding Łódź (in 2004)

Source: author based on residence cards
Other social-demographic features include the sex ratio, which was nearly equal with a slight prevalence of women $(51.32 \%)$. However, women over 75 were three times as numerous as men, (29 women to 10 men), which confirms that women live longer on average.

Considering the marital status of inhabitants ${ }^{7}$, there is a prevalence of married people $(60.59 \%)$, single people comprised $28.59 \%$ and around $5 \%$ were widowed. The level of education reached at registration was defined by less than half of the inhabitants, and the remaining consisted of both small children and adults. The largest proportion of the 1608 people had a secondary education level $(39.68 \%)$ and the rest higher, or simply vocational or primary (less than one fifth each) (Fig. 6).

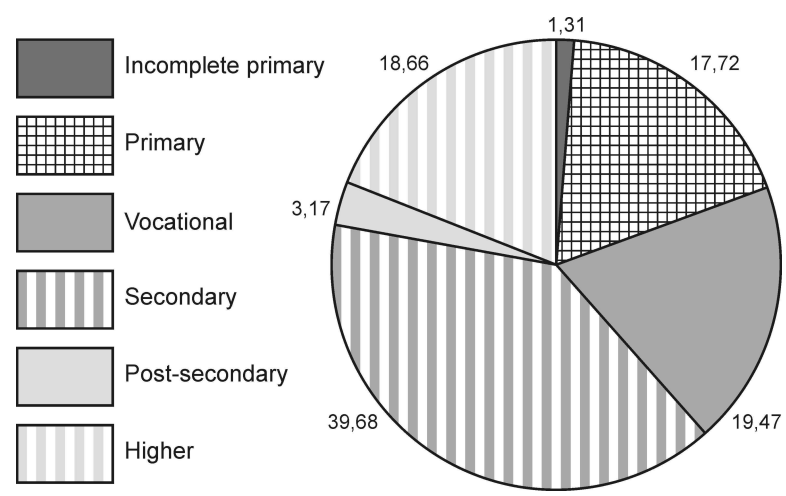

Fig. 6. Educational level of Łódź inhabitants (in \%) at the time of registering permanently in the tourism location surrounding Łódź (for 2004)

Source: author based on residence cards

A typical citizen of Łódź who decided to move permanently to a tourism location in the area surrounding the city, was a married woman of working age $(30+)$ from Górna or Bałuty districts, working in a service industry, with at least secondary education, and who made the decision to move in the early 2000s.

Among the surveyed population, as many as $81.13 \%$ lived in a block of flats before. This might be the main factor that influenced the choice to move as were their natural attractions, proximity to the big city and the desire to own a house, mentioned by as many as $75 \%$ (Fig. 7). $9.41 \%$ in total chose affordable price, good infrastructure and communications with the city as the most important factors.

As mentioned before, the transformation of areas surrounding the city is influenced not only by permanent migrations but also by temporary tourism visits. The effects of urbanisation are caused not only by (new) inhabitants but also tourists, especially those who visit on a seasonal basis and have their own plots of land, usually with a building. Important factors are the frequency, duration and form of their tourism and recreational activity on these areas. Some plot owners, depending on their preferences and the kind of house 
they own, live there for several months a year, creating a kind of 'new settlement'. Those who work in the city, commute as they own cars or use public transport (buses, trams and trains).

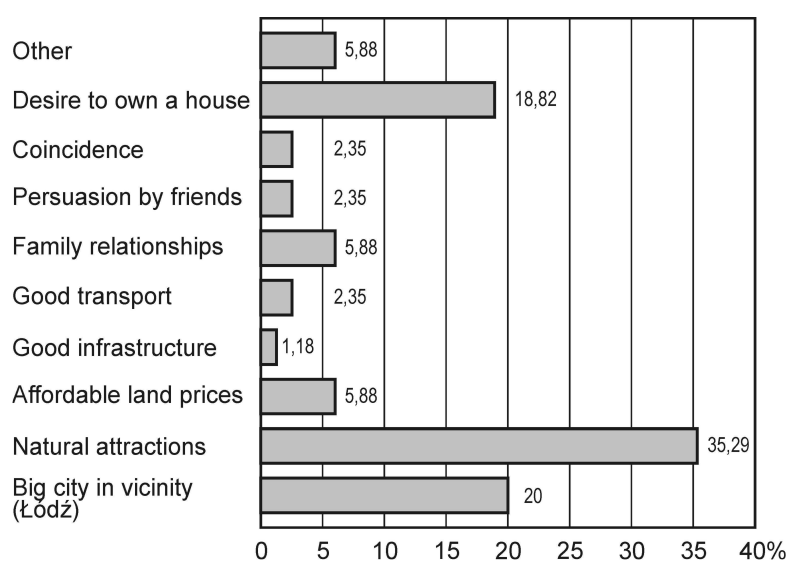

Fig. 7. Decisive factors in the process of settling in areas surrounding a large city: survey answered by former inhabitants of Łódź (in \%)

Source: author based on own research from 2004-05

The inhabitants of Łódź were the largest group $(59.6 \%)$ among the 24,936 plot owners in the 24 locations surveyed near Łódź in 2004. They usually owned properties in wooded areas, situated a bit farther (not directly on the border) from the city, on a large number of small plots that had been used for recreation for an extended period of time.

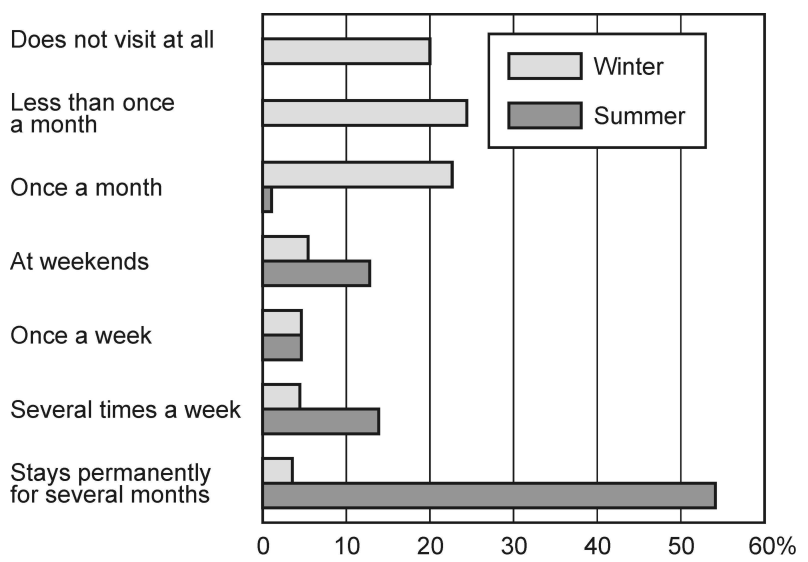

Fig. 8. Frequency of visits/use of plots in the areas surrounding the city by people permanently living in Łódź (in \%) Source: author based on own research in 2004-05

Plot owners surveyed living permanently in Łódź made up $86.24 \%$ of the total, with most living in blocks of flats $(84.04 \%)$ and tenements $(10.64 \%)$; mostly in Bałuty $(29.11 \%)$ and Polesie $(25.32 \%)$ and in Górna $(21.52 \%)$. Most were middle aged (57 on average), female $(63.83 \%)$, and married $(82.90 \%)$ having one or two adult children. Their education level was secondary $(44.68 \%)$ or higher $(39.36 \%)$.

As many as $54.13 \%$ said they stayed at their plots in summer for up to several months and spent their holidays there $(81.18 \%)$, commuting to work, usually to the city. Others regularly visited their plots during warmer months (Fig. 8). In winter, however, one fifth of the plot owners do not visit mostly because their houses are not adapted for the cold of winter. The most popular reason for buying a plot was proximity to home, the need for recreational and natural attractions (67.53\% of all answers), some mentioned family relationships, good transport connections and the price of land (Fig. 9).

Over one third of the surveyed owners are planning to reside permanently, and the rest are considering such a possibility in the future but lack the necessary technical, housing or financial conditions.

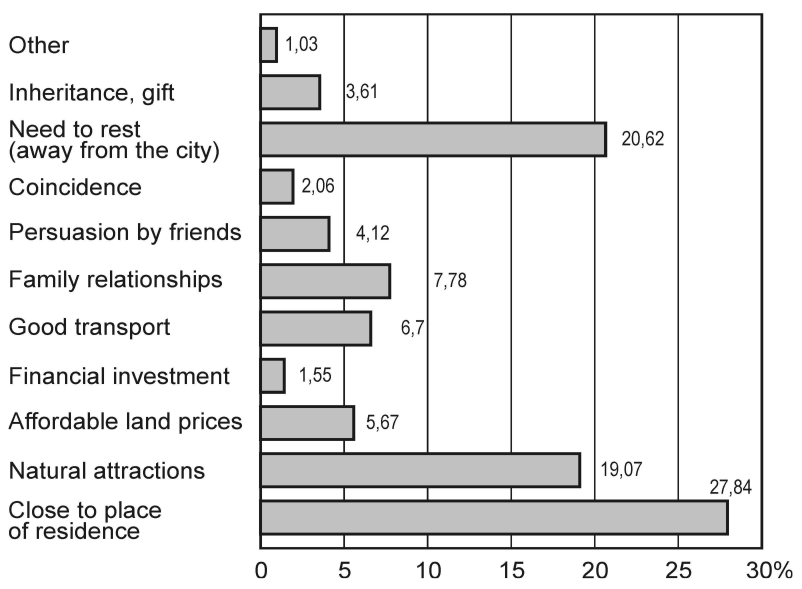

Fig. 9. Main reasons for buying a plot in the tourism area surrounding Łódź (in \%)

Source: author based on own research in 2004-05

In general, influence on tourism areas surrounding a city increases with the number of visitors and the length of their visits. The effects can be environmental (pressure on the natural environment, transforming natural habitats) and social (changes in the demographic, professional and cultural structure and new behavioural patterns). Other effects can be morphologic-physiognomic (through the changes in land use, more intense development and new buildings) or economic (activation and new functions in the urbanised area).

Initial colonisation of gminas near a big city was connected with the division and selling of agricultural and wooded land as recreational plots causing a change in land use. Now, the transformation processes are concentrated around changes in the development and character of plots as well as function. New buildings cause physiognomic changes to recreational areas (MAKOWSKA-ISKIERKA 2013). 
The significant scale of migration from Łódź to its surrounding area is expressed in economic growth due to new businesses being established ${ }^{8}$, as well as in increased real estate trading and building (MAKOWSKA-ISKIERKA 2010). An analysis of the number of building permits since the beginning of the $21^{\text {st }}$ century alone shows the scale of the phenomenon. Between 1999 and 2003 in the 24 recreational locations studied, 1277 building permits were issued (most given to inhabitants of Łódź), and the majority (78.54\%) were for residential and not summer houses. Suburban property is a good investment, because land value rises along with rising demand, while the cost of living in the city (including taxes and residence related services) and house prices are much higher.

There were 9355 houses in the area analysed in 2004 , and nearly half of them (41.75\%) were all-year houses. Their size was usually over $60 \mathrm{~m}^{2}$, and up to $110 \mathrm{~m}^{2}$ in case of villas and recreational summer houses between 30 and $60 \mathrm{~m}^{2}$. J. KACZMAREK (1991) claims that the size of individual residence building and its territorial distribution in the area surrounding the city can be seen as an expression and gauge of its expansion into the rural area. In the area surrounding Łódź, it is mostly undertaken by its inhabitants deciding to buy or build a house in the suburban area. This phenomenon gained momentum in the early 2000's and was connected with the trend to own a house in an attractive area and with the rapidly rising price of property in the cities along with a fear of changes after Poland entered the EU.

According to the information in 'Registry of real estate tax' in the 24 locations studied near Łódź, $59.65 \%$ belonged to its inhabitants, and almost half $(30.88 \%, 2889$ houses) to people living in the gminas studied, and $8.21 \%$ belonged to people living in other parts of the Łódzkie voivodeship. It is understandable that owners of most all-year houses (74.5\%) were registered there, but it is interesting that one fifth of 3906 permanent houses belonged to Łódź inhabitants. Considering summer houses, as many as $86.64 \%$ belonged to Łódź inhabitants, and just 2.89\% to owners registered locally. The data presented again proves the dominating influence of Łódź inhabitants on urbanization in the area surrounding the city.

\section{SUMMARY}

The broad definition of tourism urbanisation encompasses changes occurring in recreational locations caused by tourism and (new) permanent residents, and in the narrow sense it applies only to plot owners who have transformed their summer houses into permanent residences. In this case, it is not always connected with a change of permanent residency, or at least not immediately ${ }^{9}$. Many decide to move only after they retire. Other inhabitants of Łódź change their place of residence and job, by opening their own business in the areas surrounding the city, tempted by the environment allowing daily contact with nature, good communal and social infrastructure and favourable taxes.

The presence of new residents (both permanent and seasonal) in tourism-recreational areas, leads to the morphological changes described in this article and leads to significant social, cultural and economic transformations, which in turn inspire economic development and activation. In the process of urbanisation, the previous functions are transformed into new ones - housing and services (more by MAKOWSKA-ISKIERKA 2011).

This article presents proof that the changes described have taken place under the influence of city residents, their needs, attitudes and actions ${ }^{10}$, and the inhabitants of Łódź have a dominating influence and share in the urbanization of the area surrounding the city. Based on the data presented (with analysis of scale, directions and reasons for migration out of Łódź, the demographic situation of the new inhabitants, the number of house building permits, the number of houses according to kind and place of residence of their owners) we can determine the detail and scale of the phenomenon.

Works by A. MATCZAK from 1980s and 90s and by S. LISZEWSKI and J. JAKÓBCZYK-GRYSZKIEWICZ from the late 1990s and early 2000s indicate the development and transformation of the areas surrounding the city, and the Łódź metropolitan area ${ }^{11}$, due to urbanization. This article emphasising the tourism and recreational locations on the borders of the metropolitan area, presents the current level of development and details of urbanization taking place there as well as its speed and direction.

Tourism urbanization should be monitored to record its progress over time and its eventual outcome. How will it change the morphology of the area? What will the dominating functions be? What will the socio-demographical features of the new residents be? Will there be a spread of the recreational function to further areas, and the urbanized locations be incorporated by the city causing a 'return' of the migrants?

The research should set the place of permanent residency against the permanent registration address, the year of plot purchasing with that of house building or adaptation of a summer house, and with the date of obtaining a registration of residence to show to what extent and which part of the location have been truly urbanized (by residents of the metropolitan city). 


\section{FOOTNOTES}

${ }^{1}$ The level of development of the recreational function was defined by A. MATCZAK (1982) on the basis of the size of the recreational area, recreational buildings and tourism.

2 The tourism (tourism-recreational) metropolitan region is a geographical space used by a metropolitan city and its supply network, and which is a destination for tourism. The city is the region's centre and is the destination or transit place for tourism, while its surrounding area is usually visited by city residents.

3 'Second homes' are properties located in rural tourism areas, used seasonally for recreational reasons, and not permanent residences of the owners.

4 Tourism space is a part of geographical space, distinguished by its function. Its creation and development is inspired by human needs for learning, recreation and experience which can only be provided by discovering and developing the environment. This space is made by man who uses it to fulfil his tourism needs (LISZEWSKI 1995).

5 Transformation of recreational locations in the area surrounding Łódź took place not only in an evolutionary way but were imposed (e.g. after World War 2 or in the 1970s) and not related to tourism, so are not stages of tourism urbanization.

${ }^{6}$ The percentage is probably bigger, but $18 \%$ of records did not include information about the previous registered residence (2071 used the current location as their present one, even though they had not been registered there since birth).

${ }^{7}$ Only 20 cards $(0.6 \%)$ did not include this information.

${ }^{8}$ Despite over half of the residents surveyed were actually working in Łódź and less than one third where they were registered.

9 Registering residence does not always mean permanent living in that place which was confirmed by some of the respondents. Younger, wealthy people especially often leave their city flat and use it occasionally (less often and less regularly) while others rent out their apartments.

${ }^{10}$ In the past, as R. SZKUP (2003) has claimed, owning a plot and a house near the city was an expression of social standing.

11 S. LISZEWSKI (2010) has described the change of the area surrounding Łódź into the Łódź Metropolitan Area. He claims that the development of the metropolitan centre has led to the development of the entire surrounding area starting intense urbanization. The outer areas that are under the influence of the metropolitan centre have become metropolitan areas.

\section{Translated by Katarzyna Zielinska}

\section{BIBLIOGRAFIA}

DĄBROWSKA M., 1996, Przemiany społeczno-ekonomiczne obszarów wiejskich pod wpływem turystyki, Turyzm, 6, 1, pp. 4962.

DZIECIUCHOWICZ J., 1995, Determinanty geograficzne $i$ spoteczno-ekonomiczne redystrybucji przestrzennej ludności aglomeracji miejskich. Przykład aglomeracji tódzkiej, Wyd. Uniwersytetu Łódzkiego, Łódź.

DZIEGIEĆ E., 1987, Przemiany osadnictwa wiejskiego pod wpływem turystyki i wypoczynku w świetle literatury, Acta Universitatis Lodziensis. Turyzm, 3, pp. 7-31.

DZIEGIEĆ E., 1988, Przemiany osadnictwa wiejskiego pod wpływem rozwoju turystyki, Acta Universitatis Lodziensis. Turyzm, 4, pp. 69-93.

DZIEGIEĆ E., 1995, Urbanizacja turystyczna terenów wiejskich w Polsce, Turyzm, 5, 1, pp. 5-56.
DZIEGIEĆ E., LISZEWSKI S., 1984, Zones suburbaines en tant que terrains de recreation pour les habitants des grandes villes polonaises, Problemy Turystyki, 2, pp. 11-21.

FARACIK R., 2006, Turystyka w strefie podmiejskiej Krakowa, Instytut Geografii i Gospodarki Przestrzennej, Uniwersytet Jagielloński, Kraków.

FARACIK R., 2011, Turystyka w Krakowskim Obszarze Metropolitalnym, [in:] M. Mika (ed.), Kraków jako ośrodek turystyczny, Instytut Geografii i Gospodarki Przestrzennej, Uniwersytet Jagielloński, Kraków, pp. 275-290.

FARACIK R., 2011, Turystyka w strefie podmiejskiej Krakowskiego Obszaru Metropolitalnego, [in:] M. Durydiwka, K. DudaGromada (eds.), Przestrzeń turystyczna - czynniki, różnorodność, zmiany, Wydział Geografii i Studiów Regionalnych, Uniwersytet Warszawski, Warszawa, pp. 149-156.

JAKÓBCZYK-GRYSZKIEWICZ J., 1988, Niektóre aspekty urbanizacji wsi w strefie podmiejskiej Łodzi, Acta Universitatis Lodziensis. Folia Geographica, 9, pp. 35-52.

JAKÓBCZYK-GRYSZKIEWICZ J., 1991, Zróżnicowanie urbanizacji wsi w strefie podmiejskiej Łodzi, Acta Universitatis Lodziensis. Folia Geographica, 13, pp. 75-99.

JAKÓBCZYK-GRYSZKIEWICZ J., 1995a, Procesy zachodzące w strefach podmiejskich dużych miast. Przykład strefy podmiejskiej Warszawy, Łodzi i Krakowa, Acta Universitatis Lodziensis. Folia Geographica, 20, pp. 221-229.

JAKÓBCZYK-GRYSZKIEWICZ J., 1995b, Wybrane aspekty rozwoju funkcji wypoczynkowej w strefach podmiejskich trzech największych miast Polski: Warszawy, Łodzi i Krakowa, Turyzm, 5, 1, pp. 67-78.

JAKÓBCZYK-GRYSZKIEWICZ J., 1998, Przeobrażenia stref podmiejskich dużych miast. Studium porównawcze strefy podmiejskiej Warszawy, Łodzi i Krakowa, Wyd. Uniwersytetu Łódzkiego, Łódź.

JAKÓBCZYK-GRYSZKIEWICZ J., 2011, Wybrane aspekty procesów suburbanizacji w Łódzkim Regionie Miejskim, [in:] S. Kaczmarek (ed.), Miasto. Księga jubileuszowa w 70. rocznice urodzin Profesora Stanistawa Liszewskiego, Wyd. Uniwersytetu Łódzkiego, Łódź, pp. 118-131.

JAKÓBCZYK-GRYSZKIEWICZ J., MARCIŃCZAK S., SIEJKOWSKA A., 2010, Dynamika i skutki procesów urbanizacji w regionach miejskich po 1990 r. na przykładzie regionu miejskiego Łodzi, Wyd. Uniwersytetu Łódzkiego, Łódź.

KACZMAREK J., 1991, Indywidualne budownictwo mieszkaniowe jako miernik ekspansji miasta na tereny wiejskie - prezentacja metody, Acta Universitatis Lodziensis. Folia Geographica, 14, pp. 171-177.

Koncepcja przestrzennego zagospodarowania kraju 2030, 2011, Warszawa, www.mrr.gov.pl.

KOTER M., 1985, Kształtowanie się strefy podmiejskiej w świetle badań historyczno-geograficznych, Acta Universitatis Lodziensis. Folia Geographica, 5, pp. 61-73.

KOWALCZYK A., 1994, Geograficzno-społeczne problemy zjawiska „drugich domów", Wydział Geografii i Studiów Regionalnych UW, Warszawa.

KRAKOWIAK B., LATOSIŃSKA J., LISZEWSKI S., MAKOWSKA-ISKIERKA M., WILUŚ R., WOJCIECHOWSKA J., WŁODARCZYK B., 2014, Research into tourism space in Poland at the "Geographical Centre" in Łódź, [in:] T. Marszał (ed.), Spatial development of contemporary Poland in Łódź University Geographical Research, Wyd. Uniwersytetu Łódzkiego, Łódź, pp. 91-118.

LISZEWSKI S., 1987, Geneza i rozwój osadnictwa wypoczynkowego w otoczeniu Łodzi, Acta Universitatis Lodziensis. Turyzm, 3, pp. 33-54.

LISZEWSKI S., 1995, Przestrzeń turystyczna, Turyzm, 5, 2, pp. 87102.

LISZEWSKI S., 1999, Przestrzeń turystyczna miasta (przykład Łodzi), Turyzm, 9, 1, pp. 51-73. 
LISZEWSKI S., 2005, Metropolitalny region turystyczno-wypoczynkowy. Przykład miasta Łodzi, Turyzm, 15, 1-2, pp. 121138.

LISZEWSKI S., 2005, Przestrzeń turystyczna w ujęciu przedmiotowym. Przyczynek do dyskusji o przestrzeni w geografii, [in:] W. Maik, K. Rembowska, A. Suliborski (eds.), Geografia jako nauka o przestrzeni, środowisku i krajobrazie, t. 1: Podstawowe idee $i$ koncepcje $w$ geografii, Łódzkie Towarzystwo Naukowe, Łódź, pp. 50-60.

LISZEWSKI S., 2010, Metropolia jako przedmiot badań naukowych i obszar dynamicznych przemian przestrzennych oraz społeczno-gospodarczych, Biblioteka Wiadomości Statystycznych, 63, GUS - Urząd Statystyczny w Łodzi, Warszawa, pp. 27-41.

MAKOWSKA-ISKIERKA M., 2004a, Przemiany morfologii osiedla wypoczynkowego na przykładzie miasta ogrodu Sokolniki, Turyzm, 14, 1, pp. 5-19.

MAKOWSKA-ISKIERKA M., 2004b, Przemiany funkcji turystycznowypoczynkowej. Przykład miasta ogrodu Sokolniki, Turyzm, 14,2 , pp. $25-40$.

MAKOWSKA-ISKIERKA M., 2005, Wybrane skutki procesów urbanizacyjnych $\mathrm{w}$ miejscowościach turystyczno-wypoczynkowych strefy podmiejskiej Łodzi, [in:] P. Lorens (ed.), Problem suburbanizacji, „Biblioteka Urbanisty”, 7, Urbanista, Warszawa, pp. 173-180.

MAKOWSKA-ISKIERKA M., 2006, Aspekt demograficzny procesu urbanizacji w miejscowościach turystyczno-wypoczynkowych strefy podmiejskiej Łodzi, Turyzm, 16, 2, pp. 129-135.

MAKOWSKA-ISKIERKA M. 2008, Etapy rozwoju procesów urbanizacyjnych zachodzących pod wpływem turystyki na terenach wypoczynkowych w strefie podmiejskiej Łodzi, [in:] I. Jażdżewska (ed.), Funkcja turystyczna miast, XXI „Konwersatorium Wiedzy o Mieście", Wyd. Uniwersytetu Łódzkiego, Łódź, pp. 163-172.

MAKOWSKA-ISKIERKA M., 2009, Procesy urbanizacyjne na terenach turystyczno-wypoczynkowych strefy podmiejskiej Łodzi, mps pracy doktorskiej, w Instytucie Geografii Miast i Turyzmu UŁ, Łódź.

MAKOWSKA-ISKIERKA M., 2010, Płaszczyzna ekonomiczna procesu urbanizacji turystycznej na przykładzie wybranych miejscowości strefy podmiejskiej Łodzi, Turystyka $i$ Hotelarstwo, 16, pp. 31-55.

MAKOWSKA-ISKIERKA M., 2011, Procesy urbanizacyjne na terenach turystyczno-wypoczynkowych strefy podmiejskiej Łodzi, Łódzkie Towarzystwo Naukowe, Łódź.

MAKOWSKA-ISKIERKA M., 2013, Konsekwencje przestrzenno-fizjonomiczne urbanizacji turystycznej w Łódzkim Obszarze Metropolitalnym, Turyzm, 23, 2, pp. 35-45.

MAKOWSKA-ISKIERKA M., WŁODARCZYK B., 2012, Podmiejskie letniska Łodzi w okresie dwudziestolecia międzywojennego, [in:] J. Kowalczyk-Anioł, M. Makowska-Iskierka (eds.), Tury- styka moda na sukces, ser. „Warsztaty z Geografii Turyzmu”, 2, Wyd. Uniwersytetu Łódzkiego, Łódź, pp. 83-112.

MATCZAK A., 1981, Tereny wypoczynkowe w strefie podmiejskiej Łodzi, Miasto, 31, 6, pp. 9-14.

MATCZAK A., 1982, Funkcja wypoczynkowa strefy podmiejskiej Ło$d z i$, mps pracy doktorskiej w Zakładzie Geografii Miast i Turyzmu UŁ, Łódź.

MATCZAK A., 1984, Dostępność komunikacyjna terenów wypoczynkowych w strefie podmiejskiej Łodzi, Przegląd Ekonomiczno-Społeczny Miasta Łodzi, 9, pp. 113-125.

MATCZAK A., 1984, Próba wykorzystania analizy morfologicznej do określenia funkcji wypoczynkowej osiedli w strefie podmiejskiej Łodzi, Problemy Turystyki, 2, pp. 93-97.

MATCZAK A., 1985, Funkcja wypoczynkowa strefy podmiejskiej Łodzi, Acta Universitatis Lodziensis. Folia Geographica, 5, pp. 299-312.

MATCZAK A., 1986, Budownictwo letniskowe w strefie podmiejskiej Łodzi, Acta Universitatis Lodziensis. Folia Geographica, 7, pp. 137-166.

MATCZAK A., 1987, Ruch wypoczynkowy w strefie podmiejskiej Łodzi, Acta Universitatis Lodziensis. Folia Geographica, 8, pp. 21-39.

MATCZAK A., 1995, Preferencje kierunkowe w lokalizacji drugich domów w łódzkiej aglomeracji miejskiej, Acta Universitatis Lodziensis. Folia Geographica, 20, pp. 231-237.

MATCZAK A., 1996, Turystyka i wypoczynek w łódzkim regionie miejskim, [in:] W. Michalski (ed.), Transformacja spoteczno-gospodarcza Łodzi na tle regionu, Łódź, pp. 99-109.

Próba delimitacji obszaru metropolitalnego Łodzi na podstawie ruchu wędrówkowego ludności w latach 1989-2007, 2008, Urząd Statystyczny w Łodzi, Łódź.

Ruch turystyczny w Łodzi i województwie tódzkim w 2011 r., 2012, B. Włodarczyk (ed.), ROTWŁ, Łódź.

Roczniki statystyczne województwa tódzkiego, Urząd Statystyczny w Łodzi, Łódź, www.lodz.stat.gov.pl.

STEJSKAє J., 1992, Podmiejskie rezydencje burżuazji łódzkiej i ich funkcje dawniej i obecnie, Turyzm, 2, 2, pp. 25-44.

Studium wiedzy o regionie tódzkim. Rozwój turystyki w regionie tódzkim, 1995, Łódzkie Towarzystwo Naukowe, Łódź.

SZKUP R., 2003, Kształtowanie podmiejskiej przestrzeni wypoczynkowej. Przykład zachodniego sektora strefy podmiejskiej Łodzi, Wyd. Uniwersytetu Łódzkiego, Łódź.

Tourisme et loisir dans les environs des grandes villes. Tourism and recreation in the surroundings of big towns, 1983, Commission of the Geography of Tourism and Leisure IGU, Łódź.

WŁODARCZYK B., 1999, Przemiany form aktywności turystycznej. Przykład krawędzi Wyżyny Łódzkiej, ser. „,Szlakami Nauki”, 29, Łódzkie Towarzystwo Naukowe, Łódź.

ZIóŁKOWSKI J., 1965, Urbanizacja, miasto, osiedle. Studia socjologiczne, PWN, Warszawa. 